\title{
Peertechz
}

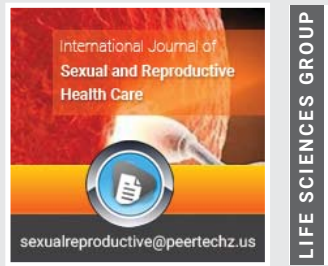

\section{Fertility intentions and}

\section{associated factors of}

\section{HIV positive women of}

reproductive age in JOS,

Northcentral Nigeria

\section{Gabriel Adah ${ }^{1 *}$, Ruth Adah' ${ }^{2}$, Hadiza Agbo ${ }^{3}$ and Ayuba Zoakah $^{3}$}

${ }^{1}$ National Primary Health Care Development Agency, Port-Harcourt Crescent, off Gimbiya Street, Area

11, PMB 367, Garki, Abuja, Nigeria

${ }^{2}$ Department of Pediatrics, Jos University Teaching Hospital, Jos, Nigeria

${ }^{3}$ Department of Community Medicine, College of Health Sciences, University of Jos, Nigeria

Received: 25 May, 2020

Accepted: 23 March, 2021

Published: 24 March, 2021

*Corresponding author: Gabriel Adah, National Primary Health Care Development Agency, PortHarcourt Crescent, off Gimbiya Street, Area 11, PMB 367, Garki, Abuja, Nigeria, Tel: +234-7036768700; E-mail: drgabadah@yahoo.com

Keywords: Fertility intentions; Human immunodeficiency virus; Women; Reproductive age

https://www.peertechzpublications.com

\section{Check for updates}

\section{Abstract \\ Background: With the improvement in the quality of life of women living with Human Immunodeficiency Virus /Acquired Human Immune deficiency syndrome (HIV/ AIDS)in recent times, heir fertility desires have been shown to be changing. In spite of this, not much has been documented of the fertility intentions of these women in Jos. Therefore, our study aims to determine the fertility intentions and associated factors among HIV positive women of reproductive age accessing care in Jos University Teaching Hospital +(JUTH) Plateau State.}

Methods: It was a hospital-based cross-sectional study conducted in the APIN Centre of the Jos University Teaching Hospital in Plateau State. An intervieweradministered questionnaire was used to collect information on socio-demographics and fertility intentions from 335 HIV positive women of reproductive age from June to July 2018..Data was analyzed using SPSS version 23 software package. Univariate and bivariate statistical analysis were carried out to identify the fertility intentions and the related factors.

Results: The age range was 18 - 49 years with mean age of $37.44 \pm 6.40$ years. Fertility intentions of HIV positive women of reproductive age varied with $47.5 \%$ expressing desire for more children. Majority (92.5\%) wanted to have two or more children. More than half (56\%) wanted the next child within two years but $44 \%$ wanted them delayed till after two years. Although age, marital status, duration of marriage, number of living children and contraceptive use were found to be significantly associated with fertility intentions, the predictors of fertility desires were number of living children $(A O R=11.00, P-v a l u e-0.026)$, age $(A O R=2.231, P-v a l u e-0.033), \mathrm{Use}$ of contraceptives(AOR=0.397,P-value-0.001) and duration of marriage (AOR=5.46,P-value-0.001).

Conclusion: Women living with HIV have varied fertility intentions. The desire for more children was highest among women in the early phase of marriage and those with few surviving children. Health Care providers and policy makers need to consider increasing services and support for family planning for HIV positive women with different fertility desires. 


\section{Abbreviations}

AIDS: Acquired Immunodeficiency Disease Syndrome; APIN: APIN Public Health Initiative in Nigeria; HAART: Highly Active Anti-Retroviral Therapy; HIV: Human Immunodeficiency Virus; JUTH: Jos University Teaching Hospital; LGA: Local Government Area; NDHS: Nigerian Demographic and Health Survey; PLWHA: People Living with HIV AIDS; SPSS: Statistical Package for Social Sciences; WORA: Women of Reproductive Age

\section{Introduction}

The Human Immunodeficiency Virus Infection /Acquired Immunodeficiency Syndrome (HIV)/AIDS is a disease of public health importance because of the associated high morbidity and mortality among people that are affected [1]. However, with the advent of the Highly Active Anti-Retroviral Therapy (HAART), this is beginning to change in many high burden countries, especially in sub-Saharan Africa. Globally, it is estimated that women living with HIV constitute about $50 \%$ of the burden of HIV and in Nigeria, over $57 \%$ of the number of people living with HIV/AIDS (PLWHA) are women of reproductive age $[1,2]$. The desire of women within the reproductive age group to have children is universal and this is more so in developing countries with resultant high fertility rates [3-5]. Studies among HIV positive women have shown that there is a growing desire to bear children in spite of their status [6-8]. The desire to have children and the previously declining fertility rates of HIV infected women have been reported to be increasing in many nations such that little or no difference exists between HIV infected persons of reproductive age and those who are uninfected [9-11]. This is a cause for concern as it has the potential of increasing the population of paediatric HIV cases in the world. With the improved quality of life resulting from the use of Highly Active Antiretroviral Drugs (HAART), HIV positive women of reproductive age on the Plateau may not only have increased fertility but may also desire more children too. This has implications for planning towards related health services. Studies from all over the world have shown certain factors to be associated with the fertility intentions of women living with HIV [12-16]. However, these factors have not been extensively studied among PLWHA in Plateau state. Consequently, this study was aimed at determining the fertility intentions and associated factors of women living with HIV in JUTH, Plateau state.

\section{Materials and methods}

The study was carried out at the APIN centre of the Jos University Teaching Hospital (JUTH) which is located in Jos North Local Government Area (LGA) of Plateau State in northcentral Nigeria. The Centre caters for about 5000 women, out of which 1052 are women of reproductive age seen on the average monthly. For treatment naïve patients, clinic visits and follow up are usually monthly until one year and after which it can be adjusted depending on the patient's adherence and clinical outcomes. Study design was a facility-based cross-sectional and the study population consisted of HIV positive women of reproductive age (18-49) years, married or in union who were accessing services at the HIV clinic in JUTH. The sample size was 335 calculated using Cochrane's formula, $\mathrm{n}=\mathrm{Z}^{2} \mathrm{pq} / \mathrm{d} 2$ and increased by $10 \%$ to account for non-response bias [17]. The Jos University Teaching Hospital (JUTH)which was the largest of seven health facilities in Jos North LGA offering comprehensive HIV treatment, care and support services was selected [18] Then a systematic sampling technique was used to select the study participants.

From the monthly booking register of all clients accessing treatment, care and support services, a list of all Women of Reproductive Age (WORA) was teased out and serialized to form the sampling frame for the study. The sampling interval was estimated and simple random sampling technique by balloting was used to select the first study participant from within the sampling interval and the interval was maintained subsequently on the list until the sample size was met. The facility unique Identification number corresponding to the serial number of the selected WORA on the list was used to track and sample the participants on their respective clinic appointment days within the period of data collection, which took place between JuneJuly 2018. In the event that the selected client declines consent for participation, the next contiguous client on the list was selected without distorting the sampling interval.

A semi-structured interviewer administered questionnaire was adapted from the Nigerian Demographic and Health Survey (NDHS) 2013 survey questionnaire [19]. The questionnaire consisted of 25 questions used to obtain information on sociodemographics characteristics, parity, use of contraception and fertility intentions from the respondents. The instrument was pretested to clarify any ambiguity in the questions and to assess ease of administration on 30 subjects in a HIV/AIDS care and treatment centre in another LGA. Ethical clearance was obtained from the Jos University Teaching Hospital (JUTH) Health Research and Ethics Committee.

\section{Statistical analysis}

All data generated was analyzed using SPSS statistical software version 23. (IBM). The outcome variable in this study was the fertility intention among HIV positive women of reproductive age, which were the desire to have children, how soon and how many. The exposure or independent variables included socio-demographic factors (such as age, educational level, ethnicity, religion, and occupation), use of contraception, partner support and parity. Respondents' sociodemographic characteristics, contraceptive use, and fertility intentions were presented in frequencies and percentages. The relationship between the fertility desires and other independent variables was determined by Chi -Square test. The Odd Ratios (OR) at 95\% confidence intervals and p-values were obtained and used to identify significant associations using bivariate analysis. This was then subjected to multivariable analysis and identified Adjusted Odds Ratio (AOR) with 95\% confidence interval, p-value $\leq 0.05$ were taken as statistically significant.

\section{Limitations}

HIV/AIDS is a disease with a lot of stigma .while issues surrounding sexual behaviour and practices are very sensitive 
in our environment. Consequently, this could introduce some form of bias in the reporting of sexual behaviour such as use of contraceptives .This was minimized by ensuring that these women were reassured on the issue of confidentiality and the interview conducted in a private conducive environment where information flow was uninhibited. Secondly, as only married women or those in union were used in this study, a major limitation is that the findings are not representative of women of reproductive age living with HIV as a whole. Finally as with most cross-sectional studies, causality could not be ascertained.

\section{Results}

Table 1 displays the socio-demographic characteristics of the respondents. Three hundred thirty five participants with age range from 18 to 49 years were recruited. The mean age of the respondents was $37.44 \pm 6.40$ years. Majority $(92.5 \%)$ of the respondents were educated with secondary level education being the largest $(34.6 \%)$. Over three-quarter $(76.7 \%)$ of the subjects were Christians while the commonest (34.9\%) occupation observed was trading. The largest majority consisted of women with 2 or more children.

Table 2 shows that a little less than half $(47.5 \%)$ of the respondents desired to have more children, with over half $(56 \%)$ of those who desired to have children wanted to have the next child in less than two years' time. Out of the respondents who were desirous to have more children, the least proportions $(0.6 \% \& 6.9 \%)$ of the respondents desired only 1or 2 children only, the largest majority desired more than 2 children.

Table 3 shows that the intention to have more children among respondents was significantly associated with age. It was highest $(100 \%)$ among the age group less than 20 years and lowest at $\geq 40$ years. ( $\mathrm{p}<-0.006$ ). while smaller percentages of divorced and widowed subjects $(23.8 \%, 16)$ significantly more married respondents intended to have more children $(50.3 \% \mathrm{P}<0.022)$. the desire to have more children It was also statistically significantly associated with duration of marriage(p-0.001).

Table 4 shows a binary logistic regression model table for predictors of fertility intentions among respondents. Those women who had no living children were 11 times more likely to desire more children compared to those who had two or more living children $(\mathrm{AOR}=11.000 ; \mathrm{CI}=1.334-90.688 ; \mathrm{P}<0.026)$ The desire for more children is 5 times more likely in those who have been married for 1-5years compared to those married for more than 15 years. $(\mathrm{AOR}=5.46 ; \mathrm{CI}=2.700-11.041 ; \mathrm{P}<0.001)$.

\section{Discussion}

Being HIV positive was found not to have affected the women's fertility desire as almost half of the women had a desire for more children. This finding may be related to the fact that, in most African societies, children occupy a very special place or position in the family as well as the society at large. This was lower than other previous studies carried out in Jos, north-central Nigeria (60\%), Sagamu - southwest Nigeria (63.3\%), Abia, south-east Nigeria (63.7\%) and Maiduguri,
Table 1: Socio-demographic characteristics of study participants.

\begin{tabular}{|c|c|c|}
\hline Demographic characteristics & $\begin{array}{c}\begin{array}{c}\text { Frequency } \\
n=335\end{array} \\
\end{array}$ & Percentage(\%) \\
\hline \multicolumn{3}{|l|}{ Age group } \\
\hline$<20$ & 4 & 1.2 \\
\hline $20-29$ & 33 & 9.9 \\
\hline $30-39$ & 163 & 48.7 \\
\hline$\geq 40$ & 135 & 40.3 \\
\hline \multicolumn{3}{|l|}{ Religion } \\
\hline Christianity & 257 & 76.7 \\
\hline Islam & 78 & 23.3 \\
\hline \multicolumn{3}{|l|}{ Educational level } \\
\hline Informal & 25 & 7.5 \\
\hline Primary & 85 & 25.4 \\
\hline Secondary & 116 & 34.6 \\
\hline Tertiary & 109 & 32.5 \\
\hline \multicolumn{3}{|l|}{ Current marital status } \\
\hline Married & 308 & 91.9 \\
\hline Widowed & 21 & 6.3 \\
\hline Divorced/Separated & 6 & 1.8 \\
\hline \multicolumn{3}{|l|}{ Order of marriage $(n=308)$} \\
\hline 1 & 244 & 72.8 \\
\hline 2 & 60 & 17.9 \\
\hline 3 & 4 & 1.2 \\
\hline \multicolumn{3}{|l|}{ Number of living children } \\
\hline 0 & 8 & 2.4 \\
\hline 1 & 57 & 17.0 \\
\hline$\geq 2$ & 270 & 80.6 \\
\hline \multicolumn{3}{|l|}{ Type of marriage } \\
\hline Polygamous & 77 & 23.0 \\
\hline Monogamous & 258 & 77.0 \\
\hline \multicolumn{3}{|l|}{ Occupation } \\
\hline Unemployed & 52 & 15.5 \\
\hline Trading & 117 & 34.9 \\
\hline Farming & 28 & 8.4 \\
\hline Civil servant & 77 & 23.0 \\
\hline Employed in private establishment & 22 & 6.6 \\
\hline Artisan & 39 & 11.6 \\
\hline \multicolumn{3}{|l|}{ Husband educational level } \\
\hline None & 29 & 8.7 \\
\hline Primary & 46 & 13.7 \\
\hline Secondary & 97 & 29.0 \\
\hline Tertiary & 163 & 48.7 \\
\hline
\end{tabular}

north-east Nigeria (71.5\%) [20-23]. However, it was consistent with results obtained from studies in Oromia region and AddisAbaba in Ethiopia where similar proportion of women from the two studies expressed desire for more children $[24,25]$. On the other hand, it was higher than that observed in a study in the USA where less than a third of the women were desirous of more children [26]. The U.S.A being a developed country with 
high female literacy level and a high child survival rates may have played a key role. This difference may be due to the fact that in this study, a significant proportion of the respondents $(40.3 \%)$ were $\geq 40$ years and this may mean that most of them would have completed their family size given the practice of early marriages that is common in this region. The finding in this study that a slightly larger proportion of women did not desire more children may be due to the fact that most $(42.9 \%)$ of the respondents had completed their family size.

This study showed that $56 \%$ of those respondents who desired more children wanted them as soon as within 2 years but $44 \%$ wanted to start having children after 2 years. This may be because nearly three-quarters of these women are in the early phase (1-5years) of their marriages when the desire to procreate is highest. This is similar to a study in Ethiopia where, out of the respondents who desired children, $60 \%$ planned to have children within 2 years [24]. It may suggest that the women in this study have similar aspirations with regards to future fertility desires as other women living with HIV from other African countries. In addition, it is pertinent to point to the sub-group who desired children but wanted to have them after two years were at risk of having unmet needs especially if they fail to use contraceptives to achieve their desired reproductive intentions.

This study showed that age was significantly associated with desire for more children. This is in keeping with the findings in several other studies in Nigeria, Ghana, Ethiopia and in the developed world $[8,13,16,20,26-28]$. [8,13,16,20,26-28]. This pattern cuts across both developing and developed countries, various cultures and races. It is not surprising as this is the peak age of reproductive potential of a woman. This has serious public health implications as this is the age group with the greatest risk of transmission of the disease [29]. Another factor that was significantly associated with desire for more children in this study was duration of marriage. This is consistent with a study in Ethiopia [30]. In this study, the association was

Table 2: Fertility desires of HIV positive women.

\begin{tabular}{|c|c|c|}
\hline Variables & Frequency & Percentage \\
\hline \multicolumn{3}{|c|}{$\begin{array}{l}\text { Fertility desire } \\
\qquad(n-335)\end{array}$} \\
\hline Yes & 159 & 47.5 \\
\hline No & 176 & 52.5 \\
\hline \multicolumn{3}{|c|}{$\begin{array}{l}\text { Time within which you want next child } \\
\qquad(\mathrm{n}-159)\end{array}$} \\
\hline$<2 \mathrm{yrs}$ & 89 & 56.0 \\
\hline $2-4$ yrs & 53 & 33.3 \\
\hline$>4$ yrs & 17 & 10.7 \\
\hline \multicolumn{3}{|c|}{$\begin{array}{l}\text { Desired number of children } \\
\qquad(\mathrm{n}-159)\end{array}$} \\
\hline 1 & 1 & 0.6 \\
\hline 2 & 11 & 6.9 \\
\hline 3 & 47 & 29.6 \\
\hline 4 & 54 & 34.0 \\
\hline$\geq 5$ & 46 & 28.9 \\
\hline
\end{tabular}

Table 3: Association between demographic characteristics and respondents' intention to have more children.

\begin{tabular}{|c|c|c|c|c|}
\hline $\begin{array}{l}\text { Demographic } \\
\text { characteristics }\end{array}$ & $\begin{array}{l}\text { Intention for more } \\
\text { children } n=159(\%)\end{array}$ & $\begin{array}{c}\text { No Intention for more } \\
\text { children } \\
n=176(\%)\end{array}$ & $x^{2}$ & $\mathbf{P}$ \\
\hline \multicolumn{5}{|l|}{ Age group } \\
\hline$<20$ & $3(100.0)$ & $0(0.0)$ & 12.398 & $0.006^{*}$ \\
\hline $20-29$ & $18(52.9)$ & $16(47.1)$ & & \\
\hline $30-39$ & $88(54.0)$ & $75(46.0)$ & & \\
\hline$\geq 40$ & $50(37.0)$ & $85(63.0)$ & & \\
\hline \multicolumn{5}{|l|}{ Religion } \\
\hline Christianity & $125(48.6)$ & $132(51.4)$ & 0.612 & 0.434 \\
\hline Islam & $34(43.6)$ & $44(56.4)$ & & \\
\hline \multicolumn{5}{|l|}{ Educational level } \\
\hline None & $17(58.6)$ & $12(41.4)$ & 6.329 & 0.097 \\
\hline Primary & $39(45.9)$ & $46(54.1)$ & & \\
\hline Secondary & $46(39.7)$ & $70(60.3)$ & & \\
\hline Tertiary & $57(54.3)$ & $48(45.7)$ & & \\
\hline \multicolumn{5}{|l|}{$\begin{array}{l}\text { Current marital } \\
\text { status }\end{array}$} \\
\hline Married & $153(49.7)$ & $155(50.3)$ & 7.598 & $0.022^{*}$ \\
\hline Widowed & $5(23.8)$ & $16(76.2)$ & & \\
\hline Divorced & 1(16.7) & $5(83.3)$ & & \\
\hline \multicolumn{5}{|l|}{ Type of marriage } \\
\hline Polygamous & $38(49.4)$ & $39(50.6)$ & 0.143 & 0.705 \\
\hline Monogamous & $121(46.9)$ & $137(53.1)$ & & \\
\hline \multicolumn{5}{|l|}{$\begin{array}{l}\text { Order of marriage } \\
\qquad(n=308)\end{array}$} \\
\hline $1^{\text {st }}$ & $119(48.8)$ & $125(51.2)$ & 0.401 & 0.818 \\
\hline $2^{\text {nd }}$ & $32(53.3)$ & $28(46.7)$ & & \\
\hline $3^{\text {rd }}$ & $2(50.0)$ & $2(50.0)$ & & \\
\hline \multicolumn{5}{|l|}{$\begin{array}{l}\text { Duration of marriage } \\
\text { (yrs) }\end{array}$} \\
\hline $1-5$ & $37(69.8)$ & $16(30.2)$ & 28.474 & $0.001^{*}$ \\
\hline $6-10$ & $43(55.8)$ & $34(44.2)$ & & \\
\hline $11-15$ & $43(51.2)$ & $41(48.8)$ & & \\
\hline \multicolumn{5}{|l|}{ Occupation } \\
\hline Unemployed & $22(42.3)$ & $30(57.7)$ & 7.457 & 0.189 \\
\hline Trading & $54(45.8)$ & $64(54.2)$ & & \\
\hline Farming & $14(50.0)$ & $14(50.0)$ & & \\
\hline Civil servant & $33(42.9)$ & $44(57.1)$ & & \\
\hline $\begin{array}{c}\text { Employed in private } \\
\text { org. }\end{array}$ & $16(72.7)$ & $6(27.3)$ & & \\
\hline Artisan & $20(52.6)$ & $18(47.4)$ & & \\
\hline \multicolumn{5}{|l|}{ Husband education } \\
\hline None & $15(50.0)$ & $15(50.0)$ & 0.961 & 0.811 \\
\hline Primary & 19(41.3) & $27(58.7)$ & & \\
\hline Secondary & $45(46.9)$ & $51(53.1)$ & & \\
\hline Tertiary & $80(49.1)$ & $83(50.9)$ & & \\
\hline \multicolumn{5}{|l|}{ Income } \\
\hline$<19,000$ & $44(47.3)$ & $49(52.7)$ & 2.578 & 0.631 \\
\hline $19,000-29,000$ & $30(45.5)$ & $36(54.5)$ & & \\
\hline $30,000-40,000$ & $19(46.3)$ & $22(53.7)$ & & \\
\hline $41,000-50,000$ & $21(60.0)$ & $14(40.0)$ & & \\
\hline$>50,000$ & $45(45.0)$ & $55(55.0)$ & & \\
\hline
\end{tabular}

Citation: Adah G, Adah R, Agbo H, Zoakah A (2021) Fertility intentions and associated factors of HIV positive women of reproductive age in JOS, Northcentral Nigeria. Int J Sex Reprod Health Care 4(1): 006-0012. DOI: https://dx.doi.org/10.17352/ijsrhc.000019 
Table 4: Logistic regression of predictors of intention to have more children among HIV positive women.

\begin{tabular}{|c|c|c|c|}
\hline Variables & AOR & 95\% C.I. & P-value \\
\hline \multicolumn{4}{|l|}{ Age } \\
\hline$\leq 29$ & 2.231 & $1.066-4.668$ & $0.033^{\star}$ \\
\hline $30-39$ & 1.995 & $1,252-3.178$ & $0.004^{*}$ \\
\hline$\geq 40$ & 1.0 & & \\
\hline \multicolumn{4}{|c|}{ Marital status } \\
\hline Married & 4.935 & $0.570-42.737$ & 0.147 \\
\hline Widowed & 1.563 & $0.146-16.719$ & 0.712 \\
\hline Divorced & 1.0 & & \\
\hline \multicolumn{4}{|c|}{ Number of living children } \\
\hline 0 & 11.000 & $1.334-90.688$ & $0.026^{*}$ \\
\hline 1 & 7.386 & $3.577-15.251$ & $0.001^{*}$ \\
\hline$\geq 2$ & 1.0 & & \\
\hline \multicolumn{4}{|c|}{ Use of contraceptives } \\
\hline Yes & 0.397 & $0.255-0.618$ & $0.001^{*}$ \\
\hline No & 1.0 & & \\
\hline \multicolumn{4}{|c|}{ Duration of marriage (yrs) } \\
\hline $1-5$ & 5.460 & $2.700-11.041$ & $0.001^{*}$ \\
\hline $6-10$ & 2.986 & $1.647-5.415$ & $0.001^{*}$ \\
\hline $11-15$ & 2.476 & $1.388-4.417$ & $0.002^{*}$ \\
\hline$>15$ & 1.0 & & \\
\hline
\end{tabular}

*Statistically significant

strongest with women in their earliest phase (1-5 years) of marriage. This may be because in the African context, children are expected to follow immediately after marriage and so most women may be under pressure to produce an offspring for their spouses. The implication will be that programme managers should direct interventions more towards women in the early phase of marriage.

This study also found out that the intention to have more children was significantly associated with the number of living children. It was found that those who had no living children had the strongest association and this decreased with increasing number of living children among these women. This is similar to findings from other studies in Nigeria, Ghana, Kenya, Ethiopia and even in the developed world [13,26-28,31]. This may be because of the high mortality among infants and under-fives in most developing countries and the low life expectancies in these regions. Consequently, these women try to give birth to as many children as they believe would survive to adulthood so that they can have someone to support them in the latter part of their life.

The intention to have children was negatively associated with the use of contraceptive. This is in keeping with studies in Ethiopia and Papua New Guinea [24,32]. Similarly, a multicentre study conducted in some peri-urban communities in sub-Saharan Africa among women in the general population, showed that women who didn't want more children reported more contraceptive use compared to those who wanted more children [33]. In spite of the differences between the study population (HIV positive women versus general population of women), the findings from our study suggest that WORA living with HIV have understood the importance of family planning practices which is being taught at each clinic visit and are practicing it. In contrast, a study conducted in Ontario, Canada did not show any significant association between current contraceptive use and fertility intention [34]. Similarly the current study revealed a substantial proportion of women who didn't desire children yet were not using contraceptives, this unmet need for family planning in this group is crucial as it affects maternal health, Maternal to child transmission of HIV and it contributes in no small measure to healthcare cost to the individuals, families and governments [35].

The number of living children, use of contraceptives and duration in marriage were identified as determinants of the fertility intentions of women living with HIV.The number of living children as a predictor of the desire for more children among HIV positive women is corroborated in several other studies in Nigeria, Kenya and Ethiopia [13,30,31]. The reasons are not far-fetched as in most African societies, the presence of children determine to some degree, the success or otherwise of a union. Furthermore, the ability to bear children in most African societies, influences a woman's identity, position and status [36]. The use of contraceptives was a determinant of fertility intentions. A significantly higher proportion of those who used contraceptives had less desire for more children. This is consistent with the finding in a study in Ethiopia [24]. On the other hand, the use of contraceptives did not emerge as a reliable predictor of fertility intention in another study in Ontario, Canada [34]. This differences in findings influencing fertility intention may be a reflection of the different reasons why contraception were needed, either for spacing or for limiting family size. The duration of marriage was found to be a predictor of fertility intentions of HIV positive women in this study. It revealed that HIV positive women who were in the early phase of their marriage ( $1-5$ years duration) were five times more likely to desire more children compared to those who had been married for over 15 years. This is consistent with a study conducted in Ethiopia where it was found that marital length less than 4 years, within 5-9 years and 10-14 years were 5.5, 4.8 and 2.8 times more likely to have fertility desire as compared to those with marital length more than 15 years [31]. This may be due to the fact that most of those women who have been married for longer duration may have completed or are close to completing their family size compared to those with a shorter duration of marriage. It is also important to note that this could guide programme managers to direct specific interventions towards women in the earlier category so that they can be fully informed of their choices towards achieving reproductive health. Some studies in Ethiopia and Burkina Faso have shown that duration of HIV diagnosis, disclosure of HIV sero-status to partner and partner's sero-difference or discordance was a significant predictor of fertility desire $[29,37]$. This was, however, in contrast to the findings in this study as no significant association was found between these variables. 


\section{Conclusion}

The study highlighted the fact that women living with HIV have varied fertility intentions. The desire for more children was highest among women in the early phase of marriage and those with few children. While most that desired children wanted the next child within 2 years. Predictors of fertility desire found were contraceptive use, women less than 30 years, marriages of 1-5 years and those without children. Although the prevalence of contraceptive use among HIV positive women of reproductive ages in this study was found to be high, a substantial percentage of those who did not desire children did not use any form of contraceptives. Consequently, healthcare providers and policy makers need to pay greater attention to improving family planning services for HIV positive women while supporting those that desire pregnancies achieve healthy outcomes for mother and the unborn children.

\section{Author contribution}

A $\mathrm{G}$ conceived the presented idea, $\mathrm{AH}$ and $\mathrm{ZA}$ developed the theory and supervised the intellectual content. AG was responsible for data acquisition, analysis and along with $\mathrm{AR}$ interpretation and writing of the manuscript. All authors discussed the results and contributed to the final manuscript.

\section{Acknowledgements}

We wish to acknowledge Prof Agbaji O, Prof Ocheke A, Dr Agaba P. and the Staff of APIN JUTH for their contributions.

\section{References}

1. Uneke CJ, Duhlinska DD, Igbinedion EB (2007) Prevalence and public health significance of HIV infection and anaemia among pregnant women attending ante-natal clinics in southern Nigeria. J Health Pop Nutr 25: 328-335. Link: http://bit.ly/315VWnQ

2. UNAIDS (2017) Global reports on AIDS Epidemic 2013. Link: https://bit.ly/3cVisWc

3. Lightbourne RE (1985) Individual Preferences and fertility behaviour. In: Clelands J, Hobcraft J, editors. Reproductive Change in Developing Countries. Insight from the World Fertility Survey. London, England. Oxford University Press 165-198.

4. Anderson JE, Morris L (1981) Fertility differences and the need for family planning services in five Latin American Countries. International Family Planning Perspectives 7: 16-21. Link: https://bit.ly/315W7Q2

5. Westoff CF (1978) The Unmet need for birth control in five Asian Countries. Fam Plann Perspect 10: 173-181. Link: http://bit.ly/3IEGV63

6. Singding WS, Fathalla M (1995) From Demographic Targets to Individual Needs: The Great Transition. The UNFPA Magazine Populi 22: 18-21. Link: http://bit.ly/3cVHuV3

7. Kimani J, Warren C, Abuya T, Mutemwa R, Mayhew S, et al. (2015) Family planning use and fertility desires among women living with HIV in Kenya. BMC Public Health 15: 909. Link: http://bit.ly/3reGxfJ

8. Ogilvie GS, Pelepu A, Rample VP, Maan E, Heath K (2007) Fertility Intentions of women of reproductive age living with HIV in British Columbia. Canada. AIDS 21: 83-85. Link: http://bit.ly/3d4xzN8

9. Chen JL, Philips KA, Kanouse DE, Collins RL, Miu A (2001) Fertility Desires and Intentions of HIV-Positive Men and Women. Fam plan perspect 33: 144-152. Link: http://bit.ly/3sdjmDN
10. Terceira N, Gregson S, Zaba B, Mason PR (2003) The contribution of HIV to fertility decline in rural Zimbabwe, 1985-2000. Popul Stud 57: 149-164. Link: http://bit.ly/2QxxpGk

11. Gregson S (1994) Will HIV become a major determinant of fertility in SubSaharan Africa? J Dev Stud 30: 650-679. Link: https://bit.ly/31618YU

12. Gutin SA, Namusike F, Shade SB, Mirembe F (2014) Fertility desires and intentions among HIV positive women during the post-natal period in Uganda. Afr J Reprod Health 18: 67-77. Link: http://bit.ly/2PgTPuW

13. Iliyasu Z, Abubakar IS, Kabir M, Babashani M, Shuaib F (2009) Correlate of fertility intentions among HIV/AIDS patients in Northern Nigeria. Afr J Reprod Health 13: 71-83. Link: http://bit.ly/319KyaM

14. Kanniappan S, Jeyapaul MJ, Kalyanwala S (2008) Desire for motherhood: Exploring HIV-positive women's desires, intentions and decision making in attaining motherhood. AIDS Care 20: 625-630. Link: http://bit.ly/2PhAWlj

15. Adair T (2007) Desire for children and unmet need for contraception among HIV positive women in Lesotho. 2007. Link: http://bit.ly/3tJCKIQ

16. Mohammed F, Assefa N (2016) Determinants of desire for children among HIV positive women in Afar Region, Ethiopia: Case control study. PLos One 11: e0150566. Link: http://bit.ly/3tN8Lja

17. Araoye MO (2003) Sample size. In: research methodology with statistics for health and social science. Nathadex Publishers, Ilorin. 115-222.

18. Plateau AIDS Control Agency (PLACA). Comprehensive HIV/AIDS Treatment, Care and Support Sites in Jos North LGA.

19. Nigeria Demographic and Health Survey 2013.

20. Oladapo OT, Daniel OJ, Odusoga OL, Ayoola-Sotubo O (2005) Fertility desires and intentions of HIV positive patients at a suburban specialist center. $\mathrm{J}$ Natl Med Assoc 97: 1672-1681. Link: http://bit.ly/3ccAvbb

21. Chama C, Morrupa J, Gashau W (2007) Sex and reproduction among HIVinfected people in Maiduguri, Nigeria. J Obstet Gynaecol 27: 812-815. Link: http://bit.ly/3tJAJMQ

22. Eka PO, Ujah IOA, Musa J, Swende TZ, Achinde G, et al. (2016) Reproductive desires and intentions of HIV positive women of reproductive age attending the adult HIV clinic at Jos University Teaching Hospital, Jos, Nigeria. Trop J Obstet Gynaecol 33: 232-237. Link: http://bit.ly/2QqXvdT

23. Nduka I, Enwereji EE, Nduka EC, Eke RA (2014) Reproductive intentions of HIV positive women on ARV treatment in Abia State,Southeast Nigeria. ISRN Public Health 10: 6-13. Link: http://bit.ly/3IGJkNq

24. Mokwena K, Bogale YR (2017) Fertility intention and use of contraception among Women living with the human immunodeficiency virus in Oromia region, Ethiopia. South African Family Practice 59: 46-51. Link: https://bit.ly/395gKAe

25. Tamene W, Fantahun M (2007) Fertility desire and family-planning demand among HIV-positive women and men undergoing antiretroviral treatment in Addis Ababa, Ethiopia. Afr J AIDS Res 6: 223-227. Link: http://bit.ly/2QA6PfT

26. Chen JL, Philips KA, Kanouse DE, Collins RL, Miu A (2001) Fertility Desires and Intentions of HIV-Positive Men and Women. Fam plan perspect 33: 144-152. Link: http://bit.ly/3sdjmDN

27. Gyimah AA, Nakua EK, Owusu-Dabo E, Otupiri E (2015) Fertility preferences of women living with HIV in the Kumasi Metropolis, Ghana. Afr J Reprod Healt 19: 125-133. Link: http://bit.ly/3IEz74e

28. Melaku YA, Zeleke EG (2014) Contraceptive utilization and associated factors among HIV positive women on chronic follow up care in Tigray Region, Northern Ethiopia: a cross sectional study. PLoS One 9: e94682. Link: https://bit.ly/3vRqIVb

Citation: Adah G, Adah R, Agbo H, Zoakah A (2021) Fertility intentions and associated factors of HIV positive women of reproductive age in JoS, Northcentral Nigeria. Int J Sex Reprod Health Care 4(1): 006-0012. DOI: https://dx.doi.org/10.17352/ijsrhc.000019 
29. Businge CB, Longo-Mbenza B, Mathews V (2016) Risk factors for incident HIV infection among antenatal mothers in rural Eastern Cape, South Africa. Global Health Action 9: 29060. Link: https://bit.ly/3scE5re

30. Demissie DB, Tebese B, Tesfaye T (2014) Fertility desire and associated factors among people living with HIV attending antiretroviral therapy clinic in Ethiopia. BMC Pregnancy Childbirth 14: 382. Link: https://bit.ly/3vS2xjV

31. Wekesa E, Coast E (2014) Fertility desire among men and women living with HIV/AIDS in Nairobi slums: A mixed method study. PLoS ONE 9: e106292. Link: https://bit.ly/2PgV9xU

32. Aska ML, Chompikul J, Keiwkamka B (2011) Determinants of fertility desire among HIV positive living in the Western Province of Papua New Guinea. World Journal of AIDS 1: 198-207. Link: https://bit.ly/2Pkll52

33. OlaOlorun F, Seme A, Otupuri E, Oguntuyigbe P, Tsui A (2016) Women's fertility desires and contraceptive behavior in three peri-urban communities in SubSaharan Africa. Reprod Health 13: 12. Link: https://bit.ly/3vUvtrM
34. Loufty MR, Hart TA, Mohammed SS, Su D, Ralph ED, et al. (2009) Fertility desires and intentions of HIV positive women of reproductive age in Ontario, Canada. A cross sectional study. PLos one 4: e7925. Link: https://bit.ly/2PnekWw

35. Ola TM (2009) The socio-cultural perception and implications of childlessness among men and women in an urban area. Southwest Nigeria Soc Sci 21: 205 209. Link: https://bit.ly/3r6ZCjS

36. Yazdkhasti M, Pourreza A, Pirak A, Abdi F (2015) Unintended Pregnancy and Its Adverse Social and Economic Consequences on Health System: A Narrative Review Article. Iran J Public Health 44: 12-21. Link: https://bit.ly/3ccSSMZ

37. Simpore J, Compaore E, Sawadogo J, Djigma F, Ouermi D, et al. (2011) Human immunodeficiency virus prevention among HIV-serodiscordant couples in Burkina Faso: bioethical and cultural challenges. World J AIDS 1: 185-191. Link: https://bit.ly/3catd7C

Discover a bigger Impact and Visibility of your article publication with

\section{Peertechz Publications}

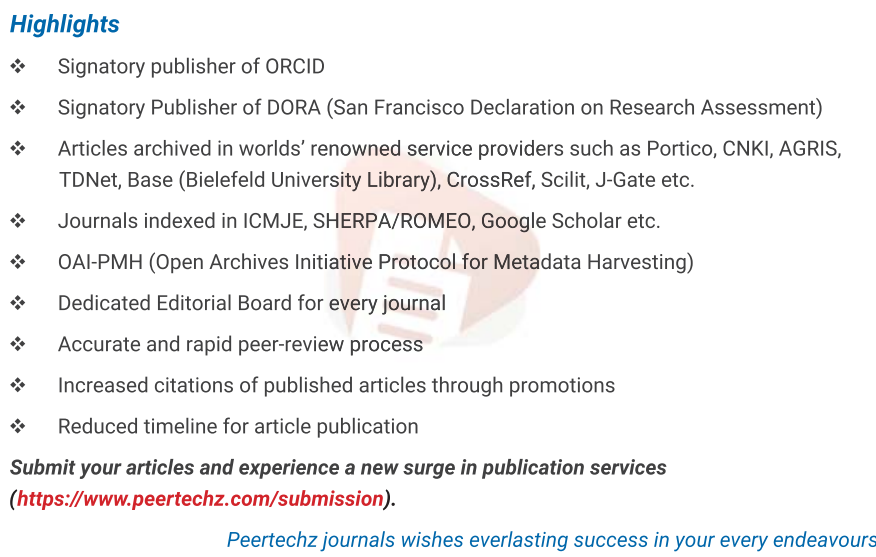

Copyright: (c) 2021 Adah G, et al. This is an open-access article distributed under the terms of the Creative Commons Attribution License, which permits unrestricted use, distribution, and reproduction in any medium, provided the original author and source are credited.

Citation: Adah G, Adah R, Agbo H, Zoakah A (2021) Fertility intentions and associated factors of HIV positive women of reproductive age in JOS, Northcentral Nigeria. Int J Sex Reprod Health Care 4(1): 006-0012. DOI: https://dx.doi.org/10.17352/ijsrhc.000019 